NBER WORKING PAPER SERIES

\title{
ECONOMICS OF ESTATE TAXATION: A BRIEF REVIEW OF THEORY AND EVIDENCE
}

\author{
Wojciech Kopczuk \\ Working Paper 15741 \\ http://www.nber.org/papers/w15741 \\ NATIONAL BUREAU OF ECONOMIC RESEARCH \\ 1050 Massachusetts Avenue \\ Cambridge, MA 02138 \\ February 2010
}

I am grateful to Kevin Hassett, Louis Kaplow and participants of the NYU Tax Law Review symposium on Lily Batchelder's "Replacing the estate tax with an inheritance tax" for many helpful comments. All errors are mine. The views expressed herein are those of the author(s) and do not necessarily reflect the views of the National Bureau of Economic Research.

NBER working papers are circulated for discussion and comment purposes. They have not been peerreviewed or been subject to the review by the NBER Board of Directors that accompanies official NBER publications.

(C) 2010 by Wojciech Kopczuk. All rights reserved. Short sections of text, not to exceed two paragraphs, may be quoted without explicit permission provided that full credit, including $\odot$ notice, is given to the source. 
Economics of estate taxation: a brief review of theory and evidence

Wojciech Kopczuk

NBER Working Paper No. 15741

February 2010

JEL No. D6,D9,H2

\section{$\underline{\text { ABSTRACT }}$}

This paper provides a non-technical overview of the economic arguments related to the desirability of transfer taxation and a summary of empirical evidence surrounding these issues. Understanding optimal transfer taxation throughout the distribution requires understanding the nature of a bequest motive, a topic on which there is little consensus. However, I argue that progress still can be made on the question of desirability and optimal level of estate taxation at the top of the distribution, because interpersonal externalities implied by the presence of bequest motive are irrelevant from the welfare point of view when the focus is on the wealthy. I also examine the role of negative externalities from wealth concentration in providing justification for considering this type of taxation.

Wojciech Kopczuk

Columbia University

420 West 118th Street, Rm. 1022 IAB

MC 3323

New York, NY 10027

and NBER

wk2110@columbia.edu 
The U.S. estate tax is in flux at the moment: it was repealed on January 1st, 2010 and is scheduled to come back in its form from 10 years ago in 2011. Hence, even inaction on the issue (something that effectively and amazingly has happened leading to this point) corresponds to major policy fluctuations in the near future. My objective here is to critically discuss economic arguments for and against taxation of transfers and empirical evidence about behavioral consequences of such taxes. My goal is not too ambitious: I am not going to advance any specific proposals but rather I will describe what I believe is our state of knowledge on this topic and what should be the key facts taken into account by policy makers when debating (if it ever happens) the future of this type of taxation.

My major points are as follows. First, disappointingly, general theoretical conclusions regarding estate taxation hinge on the nature of a bequest motive (the reason why we observe bequests in the first place) and there is little consensus about that. As a result, no broad theoretical conclusions regarding appropriate shape or even sign of marginal estate tax rates across the wealth distribution can be reached. However, there is hope that a more narrow question about appropriate taxation at the top of the distribution could be answered without taking a stand about the nature of bequest motive (though it has not been answered yet). Second, ignoring traditional redistributional considerations, I briefly examine externalities from wealth concentration as a potential justification for estate taxation. Third, efficiency effects of estate taxation exist and are possibly non-trivial, but are likely to have implications for the level of the estate tax rates and for how it is administered, rather than for its overall appeal. This is because the bulk of response appears to be along the avoidance margin rather than the wealth accumulation margin. As a result, arguments that rely on non-desirability of capital taxation are not necessarily applicable in this context (and are not bullet-proof anyway), and one is left with the trade-off between (arguably non-infinite) excess burden and potential benefits from estate taxation (such as its revenue capacity, redistributional role or correction of externalities).

\section{Bequest motives}

While there are usually many parties that are either directly or indirectly affected by any particular tax, this is particularly starkly visible in the context of transfer taxation. There are two sides to every bequest: donor's and donee's. The action of the donor (the choice 
of bequest) directly affects welfare of the donee. Because bequests are usually not bought and sold (although more on it below), there is a possible externality here: the same dollar of bequest delivers utility to both the donor and the donee, but that effect need not be fully internalized when the transfer is decided upon. In other words, when a gift is made both the donor and the donee benefit, but the decision of the donor is driven by his/her own preferences and, without well-functioning price mechanism in place, need not take full account of benefits enjoyed by the donee.

Presence of an externality has important implications for economic analysis of efficient policies because it is well-known that optimal policy involves correcting externalities. We know reasonably well how the presence of a simple externality affects the structure of optimal policy (Sandmo, 1975; Kopczuk, 2003a; Micheletto, 2008) when the externality can be targeted directly: it does so by modifying the formula for the tax imposed on the source of externality alone. This is analogous to the Pigouvian correction in a simple first-best context of being concerned with externalities alone, but the logic generalizes to second-best contexts where other taxes are used. ${ }^{1}$ In other words, as long as we can tax bequests and its bequests that generate the externality, this is what we want to do. ${ }^{2}$

At this point, I am considering an externality that actions of a donor (say, a parent) exert on a donee (say, a child). This issue is conceptually separate from redistributional considerations (that I will devote attention to later). This is a natural thing to consider in a typical economic model where the focus is on analyzing efficient policies. There are two parties involved and one way or another we care about welfare of both them, hence we should be interested in the extent to which transfers between them are not efficient. Nevertheless, a bit of introspection suggests that such an interpersonal externality is unlikely to be of the foremost importance in analyzing practical reforms of a tax that applies to a relatively small number of wealthy individuals: the correction of an interpersonal externality in that context amounts to policy makers worrying about whether there are too much or too little transfers between wealthy parents and wealthy children. While strictly speaking this is a valid issue,

\footnotetext{
${ }^{1}$ The remaining modification in the second-best context has to do with the fact that correction of externality collects revenue and hence requires adjusting all taxes accordingly.

${ }^{2}$ There is also the question of the level of corrective taxation of externality when one is not in the firstbest situation. While the literature usually focuses on formulations of the optimal tax rate that accounts for the marginal cost of raising revenue, Kaplow (2006b) shows that in the presence of optimal nonlinear tax and weak separability of preferences between leisure and other consumption goods, the optimal correction reduces to the first-best Pigouvian rate.
} 
it is not of a large consequence for the overall welfare because any welfare improvements are occurring among small number of people whose welfare should be weighted lightly in any standard welfarist approach. ${ }^{3}$ Hence, the presence of even a small cost of addressing this externality may be sufficient to eliminate the desire to correct it, the point to which I return later. Interpersonal externalities should not be ignored in a debate about transfers, but their relevance in my view is potentially important only when we are considering transfers throughout the distribution rather than transfers at the top of the distribution as is the case in the context of the present-day transfer taxation in the United States.

With this caveat in mind, I provide a brief summary of theories about bequest motives and their consequences for thinking about efficiency of transfers.

\subsection{Altruism}

Bequests may be altruistically motivated, that is donors may be directly interested in increasing welfare of donees, while respecting their preferences. The social planner likely cares about welfare of both donors and donees. One possibility is to respect donors' preferences that already put a positive weight on welfare of donees. In that case, there need not be an interpersonal externality present: donors already account for the full impact of their decisions on donees in the same way that the planner would. Alternatively, we may want to consider "double-counting" of welfare of donees: gifts to them benefit both the donors and the donees so that, in a way, it's a public good. ${ }^{4}$ Putting a positive extra weight on the donee implies that donors no longer account for the full welfare consequences of their decisions: they recognize their own benefit from child's welfare increase but not the extra benefit from counting donee's welfare separately. Hence, now, we are in the world with an interpersonal externality present. The more sophisticated analysis of these issues requires further considering the implications for the distribution of wealth and consequences of uncertainty. Recent

\footnotetext{
${ }^{3}$ Critically, the argument of Kaplow (2006b) does not apply directly in this case: the correction of externality usually should not be set at the first-best level nor is its correction related to the first-best intuition. This is because the interpersonal bequest externality is not of an atmospheric type and instead is associated with particular family lines who are weighted differently by the social planner due to differences in the level of welfare. In the extreme, the correction of externality that accrues from gifts between wealthy parents and wealthy children with negligible welfare weights (e.g., in the Rawlsian case) has no social value but requires adjusting tax structure from the otherwise optimal one.

${ }^{4}$ There has also been work on so-called two-sided altruism under which children care about welfare of their parents as well. See Laitner (1997) for a discussion.
} 
work by Farhi and Werning (2007) points out that unless some extra weight is put on welfare of donees, efficient policies have an unattractive feature of leading to an extreme concentration of wealth in the long-run. ${ }^{5}$ Hence, the unrealistic policy prescription arising from their work may be interpreted as an argument in favor of explicitly recognizing the interpersonal altruistic externality. Farhi and Werning (2008) analyze optimal tax policy in this context and find that bequests should be subsidized, with the marginal subsidy decreasing as the size of the transfer increases (so that it is in a peculiar way "redistributive").

Is altruism a reasonable theory of bequests? At the very least, we know that it is not the full theory of bequests: tests of its economic implications are routinely rejected. The best well-known example of such a test is based on the observation that altruistic bequests should be compensatory: a parent with two children should make bigger transfers to a child who is worse off. Yet, in practice, bequests are predominantly split equally between children. Some support for the desire for compensating children is provided by work of McGarry (1999) who finds evidence suggesting that inter vivos gifts may be compensatory even though bequests are not, and by Light and McGarry (2004) show that a fair number of individuals show intention of behaving in a compensatory manner. Bernheim and Severinov (2003) propose that bequests may serve as a signal of parental altruism and show that in that context equal splitting may arise.

Tests of other implications are similarly mixed. Altonji, Hayashi, and Kotlikoff (1997) test and reject another aspect of compensatory nature of altruism: a shift of resources from a parent to a child should result in a compensating decline in bequests but it does not. Hurd $(1987,1989)$ finds little difference in saving behavior between people with and without children, which he interprets as the lack of bequest motive, while Laitner and Juster (1996) and Kopczuk and Lupton (2007) similarly find little difference in bequest behavior depending on having own children, but they still do find evidence of operative (though not necessarily altruistic) bequest motive. In either case, the idea that bequeathing can be explained purely by altruism toward children does not appear to be upheld by the data, instead pointing to heterogeneity in bequest motives that is not purely driven by having children. Finally, from a more theoretical point of view, De Nardi (2004) persuasively argued that altruism is not able to generate thick upper tail of distribution of wealth observed in practice.

\footnotetext{
5 "Extreme" means here that as time goes by wealth gets concentrated among fewer and fewer individuals with the rest converging to the extreme poverty.
} 
Overall, altruism does not appear to be able to explain observed patterns of bequests, although some support for it may be found. It should also be pointed out that from the point of view of the optimal policy, altruistic preferences introduce a reason to subsidize rather than tax transfers and hence do not provide an argument for estate taxation that is observed in practice.

\subsection{Exchange}

The prominent alternative to altruistic motive are exchange-motivated or strategic bequests. The idea, articulated by Bernheim, Shleifer, and Summers (1985), is that bequests are a payment for services that the donee delivers to the donor. Many models of that kind can be constructed, with various strategic considerations coming into play (see Laitner, 1997, for a general review). Market power in the relationship can rest with the parent who is then able to extract the surplus from the relationship or it may belong to the child. Dynamic considerations where a parent cannot commit not to help a child in the future, thereby inviting inefficient behavior are also possible.

Evidence for this kind of a motive is mixed. From the normative point of view, as often when market power is present, the resulting level of bequests and the allocation do not have to be efficient so that there may be a reason for taxing or subsidizing depending on the details of the model. More importantly though, it seems again unlikely that the strategic motive could explain large bequests (see for example Carroll, 2000) and hence it appears that focusing on this kind of motivation alone cannot be relied in the analysis of the estate tax applying to the wealthy.

\subsection{Joy-of giving}

Another possible reason for leaving a bequest is the so-called "warm-glow" or "joy of giving" motive (Andreoni, 1990). The idea there is that it is the act of giving itself that provides benefits to the donor. In contrast to altruism, benefits to the donee from receiving bequests are not valued by the donor. 6 The joy-of-giving model has two versions: in the "standard"

\footnotetext{
${ }^{6}$ It had been argued that altruism and joy-of-giving are observationally equivalent (Abel and Warshawsky, 1988), that is altruistic preferences can be expressed as joy-of-giving and vice versa. However, the argument breaks down in the presence of the estate tax: the constructed "equivalent" preferences change when the
} 
one, it is the net value of bequest that matters; alternatively it may be the gross value that matters, the main source of the difference in practice being tax liability. I will discuss the latter variant a bit later, just noting at this point that the two variants could be in principle distinguished by investigating whether bequests are sensitive to tax considerations.

Joy-of-giving turned out to be a useful way of describing behavior and is often used in practice as a positive model of bequests. Taken seriously for normative purposes, it again

leads to arguments for subsidizing rather than taxing bequests, because benefits from giving to the donee are not internalized by the donor. However, joy-of-giving leads to a paradoxical prediction that encouraging gifts that are then returned to the original donor again as gifts is valuable because it is the act of giving that matters (see Diamond, 2006, for an analysis of optimal policy with these kinds of preferences in the context of charitable giving) rather than the ultimate ownership. In my view this highlights that this is a purely positive rather than normative theory: while it may be a useful way of describing behavior, paradoxical implications of this theory highlight that it is not an appealing approach for thinking about welfare.

\subsection{Accidental bequests}

A prominent theory of bequests is that they are a by-product of saving for other reasons (such as retirement or health-related expenditures). Individuals who are planning to finance their retirement out of their own wealth (rather than pensions or annuities) will usually die with some amount of wealth unspent that will then constitute a bequests. Bequests of this kind would occur even if the donor derives no benefit from bequeathing, simply as an "accident" due to (premature) death. There is a strand of economic literature that attempts to explain saving and bequests through this kind of argument, without appealing to a bequest motive (Hurd, 1989; Hubbard, Skinner, and Zeldes, 1995; Scholz, Seshadri, and Khitatrakun, 2006). While this turned out to be a very useful approach for analyzing issues related to saving behavior of general population, it is unlikely to explain the very top of the wealth distribution. In fact, even augmenting this approach by altruism cannot explain the top of the distribution (De Nardi, 2004). Hence, relevance of this approach for thinking about the estate tax is probably limited.

estate tax changes. 
This is not to say that precautionary or retirement saving motives do not play a role at the top of the distribution, but the point is simply that they are unlikely to be the full or even the most important aspect of the story. Appealing to accidental bequests is sometimes used to argue that estate taxation is not distortionary because donors are not affected by the tax. While this is true from the individual point of view, it does not follow that a confiscatory tax is optimal. Kopczuk (2003b) points out that accidental bequests of this kind arise only if individuals do not have access to well-functioning annuity markets, that is if there is some kind of market failure present. In that case though, the optimal policy response is not necessarily to take advantage of the market failure but rather to address its source (and potentially eliminate accidental bequests altogether). Even if bequests were to be confiscated, the optimal policy would likely involve transfers or tax breaks that would mimic annuities instead and hence limiting the argument to implications for the estate tax is misleading.

\section{5 "Capitalistic spirit" motive}

The idea here is that wealth itself provides benefits to the individual: for example, it can be a measure of success or the goal in itself. In the simplest form, it is very similar to the joy-of-giving motive with the caveat that estate taxes should not have an effect on behavior. As in other cases, there is an externality from giving. Similarly to accidental bequests, taxes would not distort decisions but contrary to that case this has nothing to do with underlying inefficiency and hence the case for high tax rates is stronger. Nevertheless, the notion that individuals care about wealth alone should be viewed as a positive rather than normative approach. For example, an individual may be attached to a business that he built, and this effect may be well proxied for using the value of a business. Even if the owner does not care about bequests as such, it does not necessarily follow that policies that would affect survival of the business after death of the founder are of no interest to him. It has been argued that this kind of motive is the best candidate for modeling large bequests Carroll (2000), but normative consequences have not been yet worked out. The finding of Kopczuk (2007) that wealth continues to increase with age among the elderly wealthy is consistent with this motive. It is also consistent with another finding in the same paper that much of estate planning happens following the onset of terminal illness, suggesting the desire for holding on to wealth prior to the time when death becomes inevitable. 


\subsection{Inertia and other psychological explanation}

Another possibility is that bequests are the result of psychological biases (this argument has been advocated by Fennell, 2003), such as difficulty planning, not understanding the risk, or denying the possibility of dying (Kopczuk and Slemrod, 2005). The finding of a flurry of estate planning activity following the onset of a terminal illness mentioned before (Kopczuk, 2007) could be consistent with underestimating mortality risk until death becomes inevitable. There is no consensus yet how one should go about welfare economics when people make "mistakes" (Bernheim and Rangel, 2005), and hence no clear policy implications that were derived from this kind of evidence. Nevertheless, this is certainly an interesting area for further exploration, in particular one might expect that if people deviate from economic rationality in some contexts, situations involving considering own demise are likely to be in that category.

\subsection{Combination of motives}

As the discussion above suggests, there is no consensus about the nature (and, in fact, even about the presence) of a bequest motive. Dynan, Skinner, and Zeldes (2002), among others, suggested that a combination of motives, including precautionary (or accidental) and another explicit motivation is required to make sense of the data. The unresolved difficulty is what the intentional piece should look like.

As the discussion above indicates, there are various theories of bequests with some support for each. In the tax context, we have enough evidence now to believe that bequests and gifts are somewhat responsive to tax and other economic considerations (Light and McGarry, 2004; Joulfaian and McGarry, 2004; Joulfaian, 2004), but also evidence of significant inertia (McGarry, 2000; Poterba, 2001; Brunetti, 2006; Kopczuk, 2007), and do not have a good handle on a single explanation of behavior.

Part of the problem may be that there is not simply one explanation for behavior of everyone. Indeed, evidence on the presence of bequest motives points in the direction of substantial heterogeneity (Laitner and Juster, 1996; Kopczuk and Lupton, 2007). From the point of view of analyzing optimal policy, this makes for a very disappointing landscape, because economic models require some form of assumption about the nature of preferences and there is little consensus about that in the current context. I will argue however below that 
progress can be made by concentrating on taxation applicable to the top of the distribution alone.

\section{Redistribution}

Much work has been done to understand the role of estate tax as a part of redistributive tax system. ${ }^{7}$ There are two kinds of considerations that come into play. First, as argued before, there are potential externalities associated with bequests. Second, taxes on transfers are only a part of the overall tax system.

The presence of interpersonal externalities may seem to be a nuisance that is orthogonal to redistribution. To some extent it is the case, but it comes naturally with almost all types of motives and hence is difficult to ignore when one attempts to model it formally. It is also not completely trivial in terms of how it affects the results because externalities related to giving are person-specific: their consequences are different at different places in the income/wealth distribution and hence taxes to correct them do not take a simple Pigouvian form. ${ }^{8}$

Yet, as discussed above, interpersonal externalities usually lead to the conclusion that appears questionable as far as realistic estate taxation is concerned: they call for subsidizing rather than taxing gifts. Why do I feel that this conclusion is questionable? It is because the current US transfer taxation is about the wealthy. Subsidizing gifts may well make sense for much of the public but this kind of externality should go away when we get to the top of the distribution: the marginal utility of income (or wealth) of both parents and children is low and hence the relevance of correcting bequest externalities is negligible. Hence, the focus on bequest motives and their consequences misses the point as far as understanding actual estate tax is concerned: the precise nature of a bequest motive is relevant only in so far as its welfare implications are relevant and at the top of the distribution they are not. What is relevant are revenue implications of taxing bequests, but this is an empirical question rather than theoretical one.

Estate taxation should be considered in the context of the whole tax system. Here, the

\footnotetext{
${ }^{7}$ See Batchelder (2008) for a recent overview of redistributive role of U.S. estate taxation and a proposal for its modification to improve its redistributional impact. See also Piketty and Saez (2007) for an evaluation of the contribution of estate taxation to the overall level of progressivity.

${ }^{8}$ That is not to say that a variant of the principle of targeting does not apply, see Micheletto (2008) for a general statement and Kopczuk (2001) for an application to estate taxation.
} 
question is whether estate taxation is necessary when income tax and other instruments are also available. As elaborated by Kaplow (2001), when externalities are not present, the logic of the Atkinson and Stiglitz (1976) theorem applies here: estate tax is a tax on a particular kind of consumption (bequests), and it is useful only to the extent that observing this kind of consumption helps in discriminating between high and low ability individuals. In the special case when bequests do not bring any information about abilities beyond that contained in labor income alone (technically, when preferences are weakly separable between labor and other goods), a tax on bequests is undesirable. This logic extends to the dynamic context analyzed by Farhi and Werning (2008). This is an attractive (even if preference-dependent) argument: there is a natural special case when income taxation alone is sufficient for redistribution. ${ }^{9}$

What are the limitations of this argument? It effectively assumes that the sole source of exogenous differences between individuals is ability. This is the case in static models of optimal taxation. It is also the case in dynamic models where multiple generations are considered, but with the qualification that it may be the whole history and expectations of abilities for a family that matter. This is what gives labor income its special status: labor income is the only observable potential tax base that is directly affected by wage rate, other bases (such as bequests or other goods) reflect wage rate only in so far as the price of labor affects their level through substitutability or complementarity channel.

If there was another source of exogenous differences between individuals that is reflected in wealth, the special status of being the base that allows for dealing with the exogenous source of inequality would have to be awarded to wealth as well. What could be that other source of differences? Luck is one potential candidate. Entrepreneurial ability is another. In each case, wealth would reflect both this extra attribute and decisions made by an individual, making it difficult for a social planner to elicit information about the attribute alone and giving rise to policies that are necessarily distortionary. It seems likely that if one focused on such a dimension of differences alone, the logic applying to the top marginal income tax rates would transfer to this case as well: for a realistic thick-tailed distribution of wealth, the marginal tax rate on wealth or bequests at the top would be positive (Diamond, 1998; Saez, 2001). Making this argument formally in a context with both labor market ability and

\footnotetext{
${ }^{9}$ This logic has been further pursued by Laroque (2005) and Kaplow (2006a) who show that optimality of income tax is not necessary for not relying on commodity (including bequests) taxation. Some limitations to the argument were analyzed by Saez (2002a).
} 
wealth-generating ability at the same time is bound to be harder, because our knowledge about solving problems with two dimensions of abilities is still at its infancy, but it would be an interesting direction to pursue.

I hypothesize that characterizing the marginal tax rates applying at the top of the distribution using approach similar to that pursued by Saez (2001) should be feasible and would retain conclusions linking the thick tail of the distribution with positive marginal tax rates. Assume that the welfare weights applying to the very top of the distribution are zero or converging to zero. Then, any considerations related to externalities are irrelevant. What is relevant, is the ability of taxes at the top of the distribution to collect revenue. One piece of the argument relates to thickness of the tails of the wealth and income distributions: how much wealth or income is there above any given threshold - if it is a lot relative to wealth around the threshold, then taxing it is desirable. If there is not much, then taxes should be low or zero. The second piece of the argument would involve desirability of reliance on labor income vs wealth (or bequest) tax. If labor income and wealth are closely linked, then the case for taxing wealth is hard as we are back to the Atkinson and Stiglitz (1976) logic. However, when wealth and income are driven by (to some extent) different exogenous attributes, that logic would no longer apply and one might expect taxes on both sources toward the top of the distribution.

In a dynamic context, there is a class of arguments that suggests that capital tax rates should be zero in the long-run (Judd, 1985; Chamley, 1986). Applied to the estate tax context, these arguments would suggest that taxing estates is undesirable because it is a form of a tax on capital. This logic has been challenged when there are market imperfections such as borrowing constraints (Aiyagari, 1994, 1995) or private information leading to imperfections in insurance markets (Golosov, Kocherlakota, and Tsyvinski, 2003), although simulations suggest that the challenge relates to marginal tax rates toward the bottom rather than the top of the distribution (Albanesi and Sleet, 2005). Without introducing any imperfections, Saez (2002b) illustrates that the zero capital taxation result does not preclude positive marginal tax rates for some individuals (for example, those with wealth above some high threshold) as long as the long-run level of capital stock is kept efficient by not distorting saving decisions of the rest. Overall, the argument of Judd (1985) and Chamley (1986) is probably better thought of as indicating that capital stock should be efficient rather than an argument against any capital taxation in the world with many individuals. 


\section{$3 \quad$ Wealth concentration externalities}

As is probably evident by now, I find the state of current economic analysis of estate taxation unsatisfactory. Focus on bequest motives is misguided when one is concerned with taxes toward the top of the distribution and, regardless, our knowledge about bequest motives is patchy at best. While one might think a priori that redistributional arguments could imply that estate taxation is part of the optimal policy, they have not been seriously developed in the literature beyond the case when ability is the sole source of differences between individuals (in which case, the baseline is no taxation or even subsidies).

The argument for considering estate taxation that I have not discussed yet has to do with the possibility of externalities from wealth concentration. Before justifying why externalities from wealth concentration may be of interest, let me briefly sketch what one would expect to happen. Suppose that high wealth concentration has negative effect on welfare of the society. If this is the case, then the targeting principle would call for a tax hitting wealth concentration. The current estate tax is precisely that kind of a tax: it affects only those with high wealth.

Why might one think that wealth concentration has negative economic consequences? For one thing, some of the world's worst governed countries exhibit high concentration of wealth. While correlation does not imply causality, it is at least consistent with the notion that concentration of wealth, i.e. the situation in which some individuals are "big" relative to the state, has an adverse effect on political process or constitutes a danger to democracy. This was one of the main arguments used when the estate tax was introduced in the U.S. (see Joulfaian, 1998, footnote 9 for references). A possible channel has to do with protecting monopolistic rents: monopolies are a natural source of high wealth and protecting a monopolistic position is easier when owners can affect the political process. Another possibility has to do with inability of beneficiaries to handle large fortunes: retaining control of a business within a family often implies transfer of control to children who may not possess the same entrepreneurial skills as their parents did. The negative social consequences of inefficient management in large firms may then justify an intervention that effectively prevents such a transfer of control.

Concluding, it should be pointed out that wealth concentration concerns may grow in importance in the future, although consequences of the current recession for this question 
are still largely unknown. While Scholz (2003), Kopczuk and Saez (2004) and Kennickell (2006) found that wealth concentration has not been growing much in the past 20 years despite major increases in concentration of incomes, Edlund and Kopczuk (2009) argue that this patterns reflects simultaneous decline of old wealth and rise of new (entrepreneurial) one. While in the short-term the trends may be offsetting, one would expect that increased concentration of income will eventually lead to increased concentration of wealth.

\section{Empirical evidence related to estate taxation}

So far, I concentrated on understanding the arguments that could, in theory, be made for or against estate taxation. The main conclusion is that our current state of knowledge does not allow for characterizing the full optimal estate tax schedule. However, it appears plausible that a more limited question regarding the size of the optimal tax rates at the top of the distribution can in principle be at least partially answered (although has not been yet). If one subscribes to the view that there are important negative externalities from wealth concentration, some estimate of their relevance is necessary and I am not aware of studies that would help here. However, I believe that we now have most of the piece of information that would allow for answering the purely redistributive question. The required components involve information about the distribution of income and wealth as well as the strength of behavioral responses to taxation. Reviewing evidence on the impact of transfer taxes on behavior is the topic that I turn to next.

Perhaps the most obvious question to ask is how estate taxation affects the overall size of estates. While straightforward to ask, it is extremely difficult to answer. The main conceptual difficulty has to do with the fact that one is interested in the effect on the stock of wealth and that effect accumulates over many years (and in practice many tax regimes). As a result, it is very difficult to come up with a convincing design that would allow for

establishing a causal link between tax rates and estates. Nevertheless, some attempts have been made to answer this question. Holtz-Eakin and Marples (2001) exploit cross-sectional variation in state estate and inheritance taxes, Kopczuk and Slemrod (2001) rely on multiple tax reforms and age variation to proxy for tax rates applicable over the lifetime and Joulfaian (2006) uses aggregate time-series evidence. All three papers reach fairly similar conclusion of modest elasticity of the the order of between 0.1 and 0.2 (i.e., a one percent increase 
in the marginal tax rate reduces estates by between 0.1 and 0.2 percent). Similarity of the conclusions is interesting given important differences in interpretation of the results in different studies. Holtz-Eakin and Marples (2001) use survey data and therefore are close to estimating the effect on the actual wealth. Kopczuk and Slemrod (2001) and Joulfaian (2006) rely on estate tax data and therefore estimate the effect on reported gross estates. Hence, similarity in the results may suggest that the estimated responses reflect the impact on wealth accumulation rather than avoidance. For some questions, this distinction does not matter - for example, Feldstein (1999) argued that the anatomy of behavioral response does not matter for evaluating the excess burden of taxation because any source of response has the underlying cost that's on the margin equal to the potential tax saving (marginal tax rate). However, if one is interested in understanding the effect of estate tax on wealth accumulation, the distinction becomes crucial. Trying to dismiss the importance of avoidance based on these studies is however heroic due to the number of other differences between them. By focusing on tax rates at the time of death, Holtz-Eakin and Marples (2001) and Joulfaian (2006) identify the mix of the response shortly before death and (to the extent that taxes at death are correlated with expected tax rates earlier in life) a longer term accumulation response. The preferred specification of Kopczuk and Slemrod (2001), on the other hand, corresponds to the long-term effect alone. Furthermore, Holtz-Eakin and Marples (2001) are identified off the responsiveness at relatively low levels of wealth (below federal threshold but above state ones), while other studies focus squarely on estate tax paying population. My interpretation of this evidence is that some wealth accumulation response is likely present but it is unlikely to be large.

The extent of estate tax avoidance is hard to assess. It has been long suggested that avoiding the estate tax is easy (Cooper, 1979), but this is a controversial topic. For example, Schmalbeck (2001) argues that most of tax avoidance strategies require relinquishing control over assets and that it is something that most taxpayers are reluctant to do. Aggregate studies attempting to estimate the extent of estate tax avoidance by comparing wealth holdings with estates that show up on tax returns turn out be sensitive to assumptions regarding mortality rates and inconclusive as a result (Wolff, 1996; Poterba, 2000; Eller, Erard, and Ho, 2001). Audit-based studies estimate the extent of tax avoidance at between 8 to $13 \%$ of overall tax liability (Eller and Johnson, 1999; Erard, 1999), but they are not identifying legal or unchallenged types of responses. Particular types of avoidance strategies have been given closer attention. For example, Johnson, Mikow, and Eller (2001) found 
that approximately $6 \%$ of returns claimed minority or lack-of-marketability discounts and that their average size was about $10 \%$ of gross estate (for those who claimed the discounts). Poterba and Weisbenner (2003) pursue this direction further.

A strand of the literature focused on responsiveness of inter vivos gifts to tax considerations. This is of particular interest both because the simplest avoidance strategies work through exploiting differential tax treatment of estates and gifts, and because freezing the value of estate is one of the basic avoidance strategies and is likely to require pursuing taxable gifts. It has been documented that significant number of taxpayers does not pursue the simplest strategy of taking advantage of annual gift exemption (McGarry, 1999; Poterba, 2001; Joulfaian and McGarry, 2004). At the same time, it has also been documented that taxable gifts are in fact responsive to tax considerations (Bernheim, Lemke, and Scholz, 2004; Joulfaian, 2004; Joulfaian and McGarry, 2004). The two are not necessarily inconsistent for two reasons. First, studies that find insufficient giving are based on survey data and hence population with relatively modest (among estate taxpayers) wealth, while taxable gifts studies correspond to much wealthier population. Second, it is possible that there is substantial heterogeneity in behavior even among similar taxpayers driven by heterogeneity of the presence of a bequest motive.

Kopczuk (2007) presents a richer picture of tax avoidance by focusing on behavior following the onset of terminal illness. I find that there are large adjustments to the size and structure of estates that occur in the last months of life and provide evidence that these adjustments reflect tax avoidance. This indicates that planning prior to the onset of terminal illness was not sufficient and provides support for the notion that there are important barriers to tax avoidance, perhaps related to undesirability of giving up control over assets (Schmalbeck, 2001). I also find that estates are growing with age even among the very elderly, further underscoring that avoidance is not always pursued in advance.

Overall, work on estate tax avoidance does not paint a precise picture of behavior but rather suggests important heterogeneity among otherwise similar taxpayers, different wealth groups and stages of life. ${ }^{10}$

\footnotetext{
${ }^{10} \mathrm{~A}$ number of other estate tax related issues have been analyzed in the literature. Joulfaian (2005) provides a recent review of the literature on charitable bequests, Brunetti (2006) finds suggestive evidence of the impact of estate tax on survival of family businesses and Kopczuk and Slemrod (2003) find that estate tax changes appear to affect reported date of death within days of the reform.
} 


\section{Conclusions}

In this paper, I attempted to review economics arguments related to estate taxation. My first point was negative: despite large body of work on bequest motives, we have little consensus regarding reasons that people have for leaving bequests. As a result, we do not have any compelling theoretical conclusions regarding taxation of gifts and estates: any such theory requires taking a stand on the nature of a bequest motive.

On a more positive note, I argued that understanding the precise nature of a bequest motive is irrelevant for establishing the appropriate tax rates at the top of the distribution. In general, the bequest motive matters for two reasons: because of its welfare implications and because it determines responsiveness of estates to tax rates. The first of these is close to irrelevant in the standard welfarist framework when one concentrates on the wealthy with low marginal utility of income and wealth. The second of these considerations is ultimately an empirical question that cannot be settled by theory. The empirical question can be addressed without taking a position on the nature of a bequest motive. I also hypothesized that the optimal estate tax rates at the top of the distribution are likely to be positive but precisely stating this point is an open issue.

I considered optimal taxation arguments for taxing estates and concluded that arguments having to do with redistribution for welfarist reasons are not strong. On the other hand, if there are negative externalities from wealth concentration then estate taxation could be part of the optimal tax structure. Determining whether such externalities exist is an ongoing research issue.

I briefly reviewed empirical evidence about the effect of estate tax on behavior. While the state of this literature does not allow for reaching definitive conclusions, it appears likely that both wealth accumulation and avoidance are responsive to tax considerations with neither of these effects being very large, but the bulk of response working along avoidance margin. The fact that avoidance does not appear to be very tax-sensitive does not imply that avoidance of estate tax overall is not a significant issue, because it only reflects the response on the margin starting from the situation where the marginal tax rates are already high and perhaps

avoidance is already significant. The two exceptions where significant responses were found involve large taxable gifts and behavior shortly before death.

If indeed wealth accumulation is not too responsive to tax incentives, then arguments 
related to undesirability of capital taxation do not apply in this context. Furthermore, theoretical work that suggests desirability of zero capital taxation calls for efficiency of the overall capital stock that does not imply that all individuals face zero marginal tax rates on their estates.

Finally, in a number of places I signalled potential heterogeneity in behavior. There is work documenting heterogeneity in wealth accumulation (Charles and Hurst, 2003) and bequest motives (Kopczuk and Lupton, 2007). Studies documenting insufficient inter vivos giving (McGarry, 1999; Poterba, 2001) point out to heterogeneity in how this strategy is pursued and can be reconciled with responsiveness of taxable gifts only in the presence of substantial variation in behavior among estate taxpayers. Furthermore, there appears to be ex post variation in the extent of tax avoidance pursued during life depending on whether death was preceded by a lengthy illness (Kopczuk, 2007). As a result, empirical evidence on estate taxation is likely to appear conflicting and controversial because different studies and strategies might effectively focus on different subsets of population. 


\section{References}

Abel, A. B., and M. Warshawsky (1988): "Specification of the Joy of Giving: Insights from Altruism," Review of Economics and Statistics, 70(1), 145-149.

Aiyagari, S. R. (1994): "Uninsured Idiosyncratic Risk and Aggregate Saving," Quarterly Journal of Economics, 109(3), 659-684.

(1995): "Optimal Capital Income Taxation with Incomplete Markets, Borrowing Constraints and Constant Discounting," Quarterly Journal of Economics, 103(6), 1158-1175.

Albanesi, S., And C. Sleet (2005): "Dynamic Optimal Taxation with Private Information," Review of Economic Studies, 73(1), 1-30.

Altonji, J. G., F. Hayashi, And L. J. Kotlikoff (1997): "Parental Altruism and Inter Vivos Transfers: Theory and Evidence," Journal of Political Economy, 105(6), 1121-66.

Andreoni, J. (1990): "Impure Altruism and Donations to Public Goods: A Theory of Warm-Glow Giving," Economic Journal, 100(401), 464-477.

Atkinson, A. B., And J. E. Stiglitz (1976): "The Design of Tax Structure: Direct versus Indirect Taxation," Journal of Public Economics, 6(1-2), 55-75.

BAtchelder, L. L. (2008): “A Proposal for a Comprexensive Inheritance Tax," New York University School of Law, mimeo.

Bernheim, B. D., R. J. Lemke, And J. K. Scholz (2004): "Do Estate and Gift Taxes Affect the Timing of Private Transfers?," Journal of Public Economics, 88(12), 2617-34.

Bernheim, B. D., And A. Rangel (2005): "Behavioral Public Economics: Welfare and Policy Analysis with Non-Standard Decision Makers," Working Paper 11518, National Bureau of Economic Research.

Bernheim, B. D., And S. Severinov (2003): "Bequests As Signals: An Explanation for the Equal Division Puzzle," Journal of Political Economy, 111(4), 733-764.

Bernheim, B. D., A. Shleifer, And L. H. Summers (1985): "The Strategic Bequest Motive," Journal of Political Economy, 93(6), 1045-76.

Brunetti, M. J. (2006): "The Estate Tax and the Demise of the Family Business," Journal of Public Economics, 90(10-11), 1975-93.

Carroll, C. D. (2000): "Why Do the Rich Save So Much?," in Does Atlas Shrug? The Economic Consequences of Taxing the Rich, ed. by J. Slemrod. Harvard University Press and Russell Sage Foundation, New York.

Chamley, C. (1986): "Optimal Taxation of Capital Income in General Equilibrium with Infinite Lives," Econometrica, 54(3), 607-22. 
Charles, K. K., And E. Hurst (2003): "The Correlation of Wealth acrross Generations," Journal of Political Economy, 6(111), 1155-1182.

Cooper, G. (1979): A Voluntary Tax? New Perspectives on Sophisticated Tax Avoidance, Studies of Government Finance. The Brookings Institution, Washington D.C.

De NARDI, M. (2004): "Wealth Inequality and Intergenerational Links," Review of Economic Studies, 71(3), 743-768.

Diamond, P. (1998): "Optimal Income Taxation: An Example With U-Shaped Pattern of Optimal Tax Rates," American Economic Review, 88(1), 83-95.

(2006): "Optimal tax treatment of private contributions for public goods with and without warm glow preferences," Journal of Public Economics, 90(4-5), 897-919.

Dynan, K. E., J. Skinner, And S. P. Zeldes (2002): "The Importance of Bequests and LifeCycle Saving in Capital Accumulation: A New Answer," American Economic Review, 92(2), $274-78$.

Edlund, L., And W. Kopczuk (2009): "Women, Wealth and Mobility," American Economic Review, 99(1), 146-78.

Eller, M., B. Erard, And C.-C. Ho (2001): "The Magnitude and Determinants of Federal Estate Tax Noncompliance," in Rethinking Estate and Gift Taxation, ed. by W. G. Gale, J. R. Hines Jr., and J. Slemrod, pp. 375-410. Brookings Institution Press.

Eller, M. B., And B. W. Johnson (1999): "Using a Sample of Federal Estate Returns to Examine the Effects of Audit Revaluation on Pre-Audit Estimates," Proceedings of the 1999 Meeting of the American Statistical Association, Section on Government Statistics.

Erard, B. (1999): "Estate Tax Underreporting Gap Study: A Report Prepared for the Internal Revenue Service Economic Analysis and Modeling Group," TIRNO-98-P-00406, Internal Revenue Service.

Farhi, E., And I. Werning (2007): "Inequality and Social Discounting," Journal of Political Economy, 115(3), 365-402.

_ (2008): "Progressive Estate Taxation," MIT, mimeo.

Feldstein, M. S. (1999): "Tax Avoidance and the Deadweight Loss of the Income Tax," Review of Economics and Statistics, 4(81), 674-680.

Fennell, L. A. (2003): "Death, Taxes and Cognition," North Carolina Law Review, 81(2).

Golosov, M., N. Kocherlakota, and A. Tsyvinski (2003): "Optimal Indirect and Capital Taxation," Review of Economic Studies, 70(244), 569-587.

Holtz-Eakin, D., And D. Marples (2001): "Distortion Costs of Taxing Wealth Accumulation: Income Versus Estate Taxes," Working Paper 8261, National Bureau of Economic Research. 
Hubbard, R. G., J. Skinner, and S. Zeldes (1995): "Precautionary Saving and Social Insurance," Journal of Political Economy, 103(2), 360-399.

Hurd, M. D. (1987): "Savings of the Elderly and Desired Bequests," American Economic Review, $77(3), 298-312$.

— (1989): "Mortality Risk and Bequests," Econometrica, 57(4), 779-813.

Johnson, B. W., J. M. Mikow, And M. B. Eller (2001): "Elements of Federal Estate Taxation," in Rethinking Estate and Gift Taxation, ed. by W. G. Gale, J. R. Hines Jr., and J. Slemrod. Brookings Institution Press.

Joulfaian, D. (1998): "The Federal Estate and Gift Tax: Description, Profile of Taxpayers and Economic Consequences," Office of Tax Analysis Paper 80, U.S. Department of Treasury,.

(2004): "Gift Taxes and Lifetime Transfers: Time Series Evidence," Journal of Public Economics, 88(9-10), 1917-1929.

(2005): "Estate Taxes and Charitable Bequests: Evidence from Two Tax Regimes," Office of Tax Policy Analysis Working Paper 92, U.S. Department of Treasury.

- (2006): "The Behavioral Response of Wealth Accumulation to Estate Taxation: Time Series Evidence," National Tax Journal, 59(2), 253-68.

Joulfaian, D., And K. McGarry (2004): "Estate and Gift Tax Incentives and Inter Vivos Giving," National Tax Journal, 57(2 (part 2)), 429-444.

Judd, K. L. (1985): "Redistributive Taxation in a Simple Perfect Foresight Model," Journal of Public Economics, 28(1), 59-83.

Kaplow, L. (2001): "A Framework for Assessing Estate and Gift Taxation," in Rethinking Estate and Gift Taxation, ed. by W. G. Gale, J. R. Hines Jr., and J. Slemrod. Brookings Institution Press.

(2006a): "On the Undesirability of Commodity Taxation Even When Income Taxation is Not Optimal," Journal of Public Economics, 90(6-7), 1235-50.

(2006b): "Optimal Control of Externalities in the Presence of Income Taxation," Working Paper 12399, National Bureau of Economic Research.

Kennickell, A. B. (2006): "Currents and Undercurrents: Changes in the Distribution of Wealth, 1989-2004," Discussion Paper 2006-13, Federal Reserve Board.

Kopczuk, W. (2001): "Optimal Estate Taxation in the Steady State," University of Michigan, mimeo.

(2003a): "A Note on Optimal Taxation in the Presence of Externalities," Economics Letters, 80(1), 81-86. 
(2003b): "The Trick is to Live: Is the Estate Tax Social Security for the Rich?," Journal of Political Economy, 111(6), 1318-1341.

- (2007): "Bequest and Tax Planning: Evidence from Estate Tax Returns," Quarterly Journal of Economics, 122(4), 1801-1854.

Kopczuk, W., And J. Lupton (2007): "To Leave or Not to Leave: An Empirical Investigation of the Distribution of Bequest Motives," Review of Economic Studies, 74(1), 207-235.

Kopczuk, W., And E. Saez (2004): "Top Wealth Shares in the United States, 1916-2000: Evidence from Estate Tax Returns," National Tax Journal, 57(2 (part 2)), 445-488.

Kopczuk, W., And J. Slemrod (2001): "The Impact of the Estate Tax on the Wealth Accumulation and Avoidance Behavior of Donors," in Rethinking Estate and Gift Taxation, ed. by W. G. Gale, J. R. Hines Jr., and J. Slemrod, pp. 299-343. Brookings Institution Press.

(2003): "Dying to Save Taxes: Evidence from Estate Tax Returns on the Death Elasticity," Review of Economics and Statistics, 85(2), 256-265.

(2005): "Denial of Death and Economic Behavior," Advances in Theoretical Economics, 5(1), Article 5, http://www. bepress.com/bejte/advances/vol5/iss1/art5.

LaitneR, J. (1997): "Intergenerational and Interhousehold Economic Links," in Handbook of Population and Family Economics, ed. by M. K. Rosenzweig, and O. Stark, vol. 1A. Elsevier/North Holland, Amsterdam; New York.

Laitner, J., And F. T. Juster (1996): "New Evidence on Altruism: A Study of TIAA-CREF Retirees," American Economic Review, 86(4), 893-908.

Laroque, G. R. (2005): "Indirect Taxation is Superfluous under Separability and Taste Homogeneity: A Simple Proof," Economics Letters, 87(1), 141-44.

Light, A., And K. MCGarry (2004): "Why Parents Play Favorites: Explanations for Unequal Bequests," American Economic Review, 94(5), 1669-81.

McGarry, K. (1999): "Inter Vivos Transfers and Intended Bequests," Journal of Public Economics, 73(3), 321-51.

- (2000): "Inter Vivos Transfers or Bequests? Estate Taxes and the Timing of Parental Giving," Tax Policy and the Economy, 14, 93-121.

Micheletto, L. (2008): "Redistribution and Optimal Mixed Taxation in the Presence of Consumption Externalities," Journal of Public Economics, 92(10-11), 2262-2274.

Piketty, T., And E. Saez (2007): "How Progressive is the U.S. Federal Tax System? A Historical and International Perspective," Journal of Economic Perspectives, 21(1), 3-24. 
Poterba, J. M. (2000): "The Estate Tax and After-Tax Investment Returns," in Does Atlas Shrug? The Economic Consequences of Taxing the Rich, ed. by J. Slemrod, pp. 329-349. Harvard University Press and Russell Sage Foundation, New York.

(2001): "Estate and Gift Taxes and Incentives for Inter Vivos Giving in the US," Journal of Public Economics, 79(1), 237-64.

Poterba, J. M., And S. J. Weisbenner (2003): "Inter-asset Differences in Effective Estate-Tax Burdens," American Economic Review, 93(2), 360-365.

Saez, E. (2001): "Using Elasticities to Derive Optimal Income Tax Rates," Review of Economic Studies, 68(1), 205-29.

- (2002a): "The Desirability of Commodity Taxation under Non-Linear Income Taxation and Heterogeneous Tastes," Journal of Public Economics, 83(2), 217-320.

- (2002b): "Optimal Progressive Capital Income Taxes in the Infinite Horizon Model," Working Paper 9046, National Bureau of Economic Research.

Sandmo, A. (1975): "Optimal Taxation in the Presence of Externalities," Swedish Journal of Economics, 77(1), 86-98.

Schmalbeck, R. (2001): "Avoiding Federal Wealth Transfer Taxes," in Rethinking Estate and Gift Taxation, ed. by W. G. Gale, J. R. Hines Jr., and J. Slemrod. Brookings Institution Press.

Scholz, J. K. (2003): "Wealth Inequality and the Wealth of Cohorts," University of Wisconsin, mimeo.

Scholz, J. K., A. Seshadri, And S. Khitatrakun (2006): "Are Americans Saving "Optimally" for Retirement?," Journal of Political Economy, 114(4), 607-643.

Wolff, E. N. (1996): "Discussant's Comments on Douglas Holtz-Eakin, 'The Uneasy Case for Abolishing the Estate Tax'," Tax Law Review, 51(3), 517-22. 